\title{
Characterization of cryptic prophages (monocins) in Listeria and sequence analysis of a holin/endolysin gene
}

\author{
Ralf Zink, Martin J. Loessner and Siegfried Scherer \\ Author for correspondence: Siegfried Scherer. Tel: +498161 713516. Fax: +498161714512. \\ e-mail: $100424.2340 @$ compuserve.com
}

Institut für Mikrobiologie, Forschungszentrum für Milch und Lebensmittel Weihenstephan, Technische Universität München, Vöttinger Str. 45, 85350 Freising, Germany

\begin{abstract}
Monocins in Listeria were induced by UV-irradiation of liquid cultures, and defective phage particles were purified from the lysates. Electron microscopy showed flexible, non-contractile bacteriophage-tail-like particles, consisting of specific proteins of molecular mass $20-45 \mathrm{kDa}$ and pl 4.6-6.7. These particles were able to lyse listerial cells. DNA sequence homologies between chromosomal DNA of monocin-producing strains and labelled Listeria phage DNAs were inferred from DNADNA hybridizations, suggesting that most of the prophage DNA is still present in the listerial chromosome. An endolysin gene cp/2438 was cloned from listerial chromosomal DNA and was identified by its expression of lytic activity against Listeria cells in a bioassay. The gene consists of 864 nt encoding a protein of 287 aa with a calculated molecular mass of $32975 \mathrm{Da}$ (CPL2438). This is in good agreement with the size of a protein observed in SDS-PAGE after overexpression of the lytic protein in Escherichia coli. The nucleotide sequence of a putative holin gene (ho/2438, $291 \mathrm{nt}$ ) upstream of Cp/2438 was determined after PCR-amplification of listerial DNA and it shows typical features common to the holin gene family. Expression of the encoded protein (HOL2438, 95 aa, 10.1 kDa) in E. coli was found to be lethal for the host cells. The results underline the close relationship between monocins and intact Listeria bacteriophages, indicating that monocins are incompletely assembled phage particles derived from cryptic prophages of Listeria, probably including the phage lysin.
\end{abstract}

Keywords: defective phage, monocin, Listeria, endolysin, holin

\section{INTRODUCTION}

The ability of bacteria to produce bacteriocins or defective phages is widespread. Tagg et al. (1976) suggested criteria to differentiate 'true' bacteriocins of relatively low molecular mass from larger 'bacteriocin-like' substances (Hoover, 1992; Reeves 1972). Particles morphologically related to phages, such as structures resembling phage tails, occur in a variety of Gram-positive and Gramnegative bacteria. Although they do not cause productive infection (Garro \& Marmur, 1970), some still possess lytic activity. Detailed analysis is severely hindered by their inability to form plaques. Defective phages display characteristics similar to both bacteriophages and bacteriocins. Tail length and number of cross-striations on extended tails have been used for differentiation and

The EMBL accession number for the sequence reported in this paper is X89234. characterization (Steensma et al., 1978). Some morphologically intact phages exhibit bacteriocin-like behaviour (e.g. Bacillus phage $\phi \mathrm{BA} 1$ ), and show non-productive killing activity without expression of the phage genome, which might be caused by a proteinaceous component (Ito et al., 1986). This phenomenon was also noted during phage-typing of Listeria, where otherwise resistant strains were non-specifically inhibited by concentrated phage suspensions (Loessner \& Busse, 1990).

Some of these bactericidal substances of Listeria strains were reported to be analogous to colicins or colicin-like agents (Sword \& Pickett, 1961). Other authors reported that rod-shaped particles (rhapidosomes; Reichle \& Lewin, 1967) or polysheath-tails produced during T4 infections (Moody, 1967) resemble particles isolated from Listeria, which have been described electron microscopically by Bradley \& Dewar (1966) and Bradley (1967). Since then, many Listeria strains were reported to produce bactericidal substances, previously designated as mono- 
cins or listeriocins (Hamon \& Péron, 1963; Ortel, 1978; Wilhelms \& Sandow, 1989). Curtis \& Mitchell (1992) and Mollerach et al. (1988) described these substances to be more similar to bacteriocins, but did not perform any electron microscopical examinations.

Although monocins are useful in Listeria typing (Ortel, 1978; Curtis \& Mitchell, 1992; Zink et al., 1994), none have yet been examined in detail. First, the aim of the present study was to investigate relationships between monocins and intact Listeria phages using protein data, morphological studies and DNA/DNA hybridization. Second, the molecular basis of the lytic activity of monocins was studied. Cell-wall hydrolysis by phage depends on the synthesis of endolysins (Foster, 1993; Longchamp et al., 1994; Shearman et al., 1994) and, in many cases, of holins forming pores in the cytoplasmic membrane (Arendt et al., 1994; Henrich et al., 1995; Steiner et al., 1993; Young, 1992). We show that a monocin-carrying Listeria strain in fact harbours a holinendolysin system.

\section{METHODS}

Induction of defective phages and activity testing of monocins. A set of 144 Listeria strains was initially screened for listeriocidal activity after induction with UV light $(254 \mathrm{~nm}$, $0.0132 \mathrm{~J} \mathrm{~cm}^{-2}$ ), using the soft-agar-layer method, where defective phages do not form plaques. Seven monocin producers were then selected for further studies (Table 1). Tryptose broth and agar $\left(1.2 \%\right.$, Merck) and an incubation temperature of $30^{\circ} \mathrm{C}$ were used for Listeria throughout. Listeria indicator strains from different species and serovars are given in Table 1. Thermal inactivation of monocins was determined by incubation ( $2 \mathrm{ml}$ samples) at different temperatures $(30,40,45,50$, 60,70 and $\left.80^{\circ} \mathrm{C}\right)$ and variable times $(1,2.5,5,10,15$ and $30 \mathrm{~min})$. For determination of activity at different $\mathrm{pH}$ values, dilutions of monocins were incubated for $2 \mathrm{~h}$ in SM-buffer (see below), adjusted to $\mathrm{pH} 2-12$. Thereafter, monocins were diluted 100 -fold in SM-buffer ( $\mathrm{pH} 7.5$ ) and the remaining activity was determined in comparison with untreated samples as described previously (Zink et al., 1994). In short, determination of lytic ranges was done by applying the spot-on-the-lawn technique and $24 \mathrm{~h}$ incubation. Activity was then recorded in three grades: confluent lysis, turbid zone and no lysis. The lytic range of the monocins was established using the following 41 strains of 22 genera of Gram-positive bacteria from our culture collection: Artbrobacter (2 strains); Bacillus (10); Brevibacterium (2); Brochothrix (1); Cellulomonas (1); Corynebacterium (2); Curtobacterium (1); Enterococcus (2); Erysipelotbrix (1); Jonesia (1); Kurthia (1); Lactobacillus (4); Lactococcus (2); Leuconostoc (1); Microbacterium (1); Micrococcus (2); Nocardia (1); Oerskovia (1); Pediococcus (1); Propionibacterium (1); Rhodococcus (1); and Staphylococcus (2).

Concentration and purification. Two litres of a UV-induced culture $\left(6 \mathrm{~h}\right.$ incubation at $\left.30^{\circ} \mathrm{C}\right)$ were centrifuged at $22000 \mathrm{~g}$ $\left(20 \mathrm{~min}, 10^{\circ} \mathrm{C}\right)$. Bacterial cells were removed from the supernatant by a passage through a $0.22 \mu \mathrm{m}$ pore-size filter and subsequently concentrated by ultrafiltration to a final volume of $150 \mathrm{ml}$ (molecular mass cut-off $>20 \mathrm{kDa}$; Sartocon Mini Crossflow system, Ultrasart module, Sartorius). Monocins were precipitated overnight at $4{ }^{\circ} \mathrm{C}$ with $10 \%$ (w/v) PEG-8000 (Yamamoto et al., 1970), collected by centrifugation $(15000 \mathrm{~g}$, $20 \mathrm{~min}, 4^{\circ} \mathrm{C}$ ), and resuspended in $3 \mathrm{ml} \mathrm{SM}$-buffer (Sambrook et al., 1989). Chloroform-extraction eliminated residual PEG8000. Particles were then purified on a pre-formed stepped $\mathrm{CsCl}$ gradient (density $1 \cdot 1-1.5 \mathrm{~g} \mathrm{~cm}^{-3}$ ) at $93000 \mathrm{~g}$ for $15 \mathrm{~h}$ at $4{ }^{\circ} \mathrm{C}$. Opalescent bands at a buoyant density of approximately $1.3 \mathrm{~g}$ $\mathrm{cm}^{-3}$ were collected, washed in SM-buffer $(216000 \mathrm{~g}, 90 \mathrm{~min}$, $4^{\circ} \mathrm{C}$ ), and resuspended in Milli-Q water (Millipore).

Electrophoretic analyses of proteins and electron microscopy. These were performed as described by Zink \& Loessner, (1992) and Loessner et al. (1994b).

Extraction and purification of Listeria genomic DNA. Cells were lysed as described by Loessner et al. (1995a). Samples were deproteinized by extractions with phenol and chloroform. The

Table 1. Monocin producers and indicator strains of Listeria

\begin{tabular}{|lcll|}
\hline Species & Serovar & WSLC code & Origin, synonym $\dagger$ \\
\hline Monocin producers & & & \\
L. monocytogenes & '7' & 1034 & SLCC 2482 \\
L. monocytogenes & $1 / 2 \mathrm{a}$ & $1040^{*}$ & SLCC 53/ATCC 15313 \\
L. monocytogenes & $1 / 2 \mathrm{a}$ & 1132 & Food \\
L. innocua & $6 \mathrm{a}$ & $2011^{*}$ & SLCC 3379/ATCC 33090 \\
L. innocua & $6 \mathrm{~b}$ & 2438 & Food \\
L. ivanovii & 5 & $3010^{*}$ & SLCC 2379/ATCC 19119 \\
L. welsbimeri & $6 \mathrm{~b}$ & $5008^{*}$ & SLCC 5334 \\
Indicator strain & & & \\
L. monocytogenes & $4 \mathrm{~b}$ & 1003 & SLCC 2375/ATCC 19115 \\
L. monocytogenes & $4 \mathrm{c}$ & 1019 & SLCC 2376/ATCC 19116 \\
L. monocytogenes & 67 & 1034 & SLCC 2482 \\
L. monocytogenes & $4 \mathrm{~b}$ & 1042 & ATCC 23074 \\
L. innocua & $6 \mathrm{~b}$ & 2023 & SLCC 5640 \\
L. ivanovii & 5 & 3009 & SLCC 4769 \\
\hline
\end{tabular}

* Type strains.

† ATCC, American Type Culture Collection, Rockville, MD, USA; SLCC, Special Listeria Culture Collection, Würzburg, Germany; WSLC, Weihenstephan Listeria Collection, Freising, Germany. 
DNA was then ethanol precipitated, resuspended in TE-buffer (Sambrook et al., 1989), and stored at $4{ }^{\circ} \mathrm{C}$. Concentrations were determined photometrically.

DNA/DNA hybridizations. Purified DNA from monocin-producing strains was spotted $(0.25 \mu \mathrm{g}$ DNA per spot) onto positively charged nylon membranes (Boehringer), and covalently linked to the membranes by UV irradiation $\left(0.7 \mathrm{~J} \mathrm{~cm}^{-2}\right.$, $312 \mathrm{~nm})$. DNA from 19 different Listeria phages of various morphological types and species (A511, A005, A006, A500, A502, A620, A640, B021, B025, B035, B054, B056, B101, D441, 10072, 13441, 90666, 90861, PSA; Zink \& Loessner, 1992; Loessner et al., 1994a, b) were digoxigenin-labelled (RandomPrimed DNA Labelling kit, Boehringer), and hybridized to the membrane-bound Listeria chromosomal DNA. Hybridization and signal detection were performed under high-stringency conditions by chemiluminescence as described previously (Loessner et al., 1994b). DNA from selected monocin-producers displaying strong dot-blot signals (Listeria WSLC1040/phage A005, WSLC1132/A005, WSLC2438/A500 and WSLC2438/ A620), were then ClaI-digested and Southern-hybridized to the respective phage DNAs.

Cloning and sequencing of the endolysin gene. For expression-library construction, DNA of the monocin producer WSLC2438 was partially digested with TaqI (Promega) and separated by agarose gel electrophoresis. Fragments between 1.5 and $3.5 \mathrm{~kb}$ were excised from $0.8 \%$ low-melting-point agarose gels (SeaPlaque GTG, FMC Bioproducts). After $\beta$ Agarase (USB) digestion and concentration by ultrafiltration (Microcon-100, Amicon), DNA-fragments were inserted (T4 DNA ligase, Boehringer) into plasmid pSP72 (Promega), which had been linearized with ClaI (Boehringer). Ligation products were de-salted and transformed by electroporation into $E$. coli JM109(DE3). For preparation of competent cells, see Dower $e t$ al. (1988). To detect lysin activity, replicas from the original plates were created on plates containing $0.4 \mathrm{mM}$ IPTG. After $5 \mathrm{~h}$, cells were exposed to saturated chloroform vapour for $5 \mathrm{~min}$, overlaid with a $5 \%$ inoculum of a 100 -fold-concentrated culture of Listeria in $0.4 \%$ agar, and incubated at room temperature for $1-3 \mathrm{~h}$.

The nucleotide sequence of the DNA fragment present on pCPL2438 was determined by the dideoxy chain-termination method according to the manufacturer's instructions (Sequenase version 2.0, USB), using a primer-walking strategy.

Cloning of the holin gene. The holin gene was amplified by PCR from chromosomal DNA of WSLC2438. A holin downstream primer (5'-ACATGAATTCATGATGAAAATGGAGTTTGGAAAAGAGTTACT-3') was deduced from the short nucleotide sequence upstream of the lysin gene $c p / 2438$. The holin upstream primer (5'-ATCAGAATTCTTAT'TAATCATCC'T'TCCATATTTT'TTAGCTC-3') was inferred from a closely related holin gene (bol500) of Listeria phage A500 (Loessner et al., 1995b). Both primers included a 5' EcoRI site (underlined). PCR was performed with Taq polymerase according to the manufacturer's instructions (PCR-Core kit, Boehringer). PCR products were extracted with phenol and chloroform, ethanol precipitated, and resuspended in $0.1 \times$ TEbuffer ( $\mathrm{pH} 8 \cdot 0$ ). After EcoRI digestion, fragments were ligated into pBluescriptII (Stratagene) and transformed into $E$. coli DH $5 \alpha$ (Life Sciences). Screening for hol2438 recombinant clones was done by $\alpha$-complementation on IPTG- and X-Gal-supplemented agar plates, and by restriction enzyme analysis of isolated plasmids. Nucleotide sequencing of the insert was performed as described above.

DNA sequences and proteins translated from the putative ORFs were analysed by the DNASIS/PROSIS program package (Hitachi). We used GenBank (R81.0) and EMBL (R38.0) databases for DNA analyses, and NBRF-PIR (R40.0) and Swiss-Prot (R28.0) for protein analyses, respectively.

\section{RESULTS}

\section{Monocins resemble phage tails and specifically kill listeriae}

Electron microscopy revealed that all monocins investigated are similar to bacteriophage tails (Fig. 1a) and resembled flexible, non-contractile tails, which are uniform in size (about 110-120 nm long and $11 \mathrm{~nm}$ wide) and have 25-26 striations. Occasionally, a few assemblies of phage tails attached to apparently empty heads and various rod-shaped structures resembling long tubes were observed (Fig. 1b). Electron microscopic observation of cell lysis after incubation of sensitive cells with monocins M1040 and M2438 demonstrated that the total cell surface was covered with adsorbed particles (Fig. 1c). Ruptures and cytoplasmic efflux were obvious and monocins were attached only by their receptor structure to the cell wall (Fig. 1d). Adsorption was strain-specific, and none of the other Gram-positive genera tested were sensitive to monocins.

\section{Protein composition and stability of monocins}

The particles exhibited protein patterns with major bands ranging from 30 to $31 \mathrm{kDa}$ and some weak minor proteins (Fig. 2a). Monocin M1040 was somewhat different with proteins of approximately 20,21,23, 29 and $45 \mathrm{kDa}$. Protein patterns obtained by isoelectric focusing are depicted in Fig. 2b. All monocins investigated showed one (or more) dense protein bands and a number of weak bands. Most proteins had pIs between $\mathrm{pH} 4.9$ and 5.1 . M1040 revealed proteins in the $\mathrm{pI}$ range of $\mathrm{pH} \mathrm{4 \cdot 6-6 \cdot 7.}$ Monocin activity was found to be stable between $30^{\circ} \mathrm{C}$ and $40^{\circ} \mathrm{C}$, and $\mathrm{pH} 3-11$. During $12 \mathrm{~min}$ at $45^{\circ} \mathrm{C}$, activity was reduced by approximately $50 \%$. However, $50^{\circ} \mathrm{C}$ completely inactivated lytic activity. Storage at $4{ }^{\circ} \mathrm{C}$ for some weeks had little or no effect on monocins, and monocins were stable during storage at $-20^{\circ} \mathrm{C}$.

\section{Homology with DNA of intact Listeria phages}

Fourteen of 19 Listeria phage DNAs hybridized to the DNA of one or more monocin-producing Listeria strains. None of the Myoviridae phages (morphotype A1: A511, B054; Zink \& Loessner, 1992) showed any homology, neither did 3 of the 17 Siphoviridae (morphotype B1) tested. Strong hybridization signals were observed between monocin-producing Listeria strains WSLC1034, WSLC1132, WSLC2438 and phages A500, A006, B025, A620 and A005 (Fig. 3a). Listeria strains WSLC1040, WSLC2011 and WSLC3010 showed weak or no signals. Southern blots with ClaI-digested DNA (Fig. 3b) enabled us to summarize the size of all labelled fragments, resulting in $35-40 \mathrm{~kb}$, which reflects the genome size of intact Siphoviridae phages (Loessner et al., 1994b). 

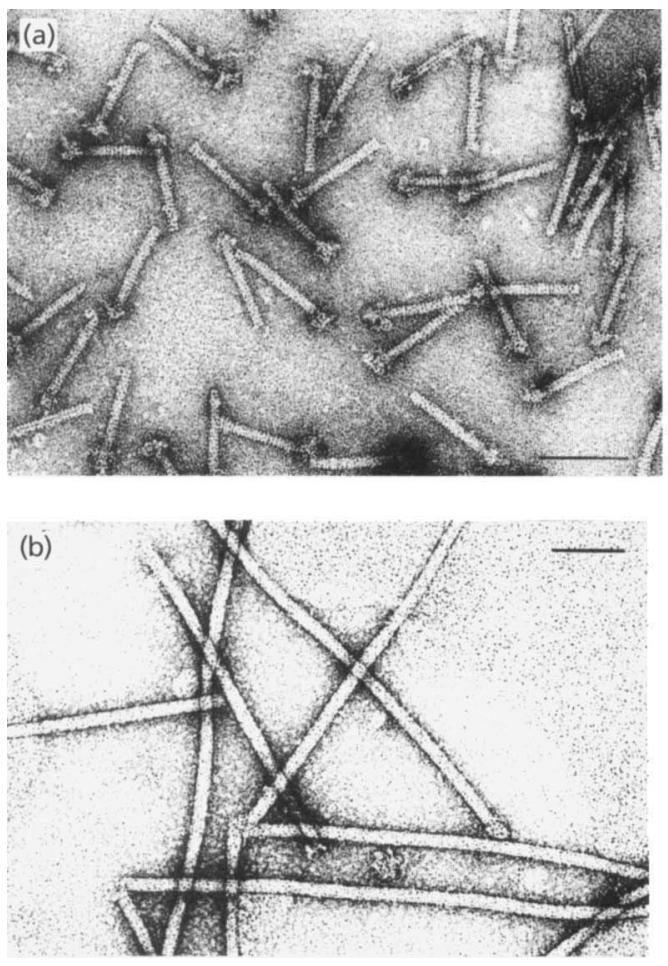
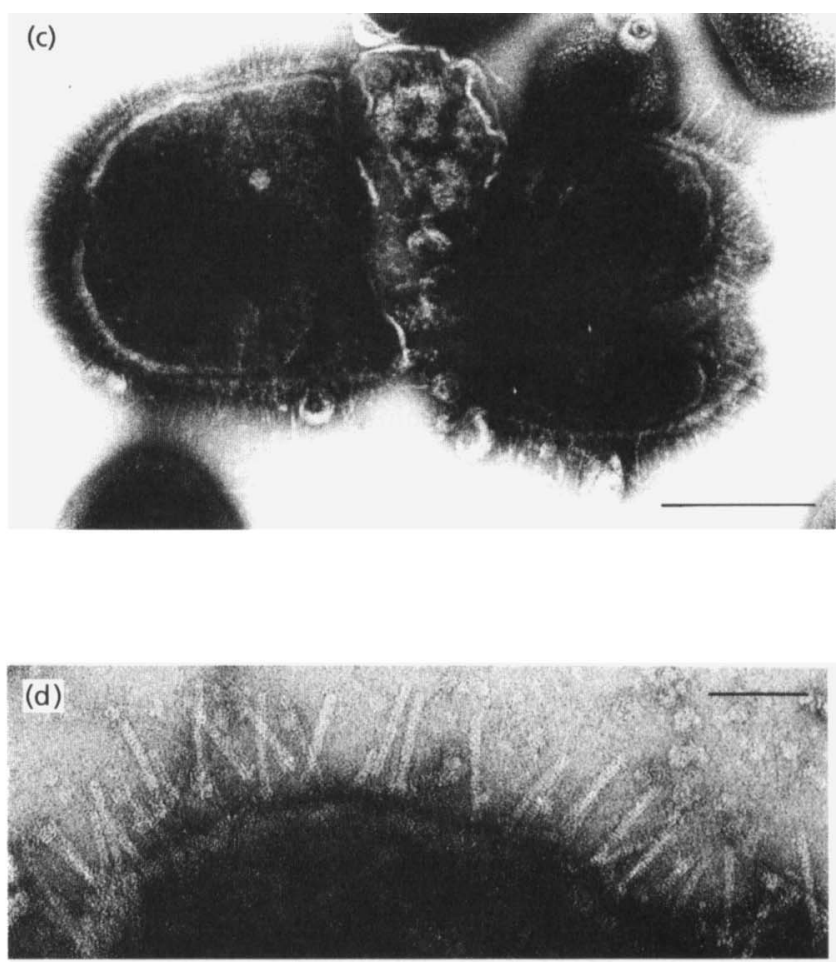

Fig. 1. (a) Monocin M1040; bar, $100 \mathrm{~nm}$. (b) Rod-shaped structures observed in some monocin preparations (M2011); bar, $100 \mathrm{~nm}$. (c) Listeria cell (WSLC 3009) lysed by monocin M1040 after 30 min incubation: cell wall is severely destructed; bar, $500 \mathrm{~nm}$. (d) Enlarged section of the cell surface with monocin particles attached; bar, $100 \mathrm{~nm}$. All specimens were negatively stained with $2 \%$ uranylacetate.

\section{Monocin-producing Listeria WSLC2438 harbours a lysin gene (cp/2438)}

Expression and screening of clones containing DNA fragments of strain WSLC2438 led to the identification of a clone with lytic activity against Listeria cells. When induced with IPTG, colonies showed a clear inhibition zone in a lawn of Listeria cells in an overlay test on agar plates after $30 \mathrm{~min}$ (Fig. 4a). Restriction analysis of the isolated plasmid showed the presence of a $2 \cdot 1 \mathrm{~kb}$ DNA insert. The nucleotide sequence was determined and revealed an $864 \mathrm{nt}$ ORF, encoding a protein of 287 aa with a calculated molecular mass of $32975 \mathrm{Da}$ (Fig. 5). The start codon was preceded by a possible RBS. A $20 \mathrm{~kb}$ band from ClaI-digested DNA fragments from monocinproducing Listeria hybridized with digoxigenin-labelled pCPL2438, carrying the $0.9 \mathrm{~kb}$ fragment of $c$ pl2438 (Fig. $3 \mathrm{~b})$. Extensive hybridizations with 22 monocin-producing strains revealed that only six strains (WSLC1034, WSLC1132, WSLC2105, WSLC2438, WSLC3010, WSLC5008) exhibited positive signals.

\section{A putative holin gene (ho/2438) is located upstream of $c p / 2438$}

Upstream of the endolysin gene, the $2.1 \mathrm{~kb}$ fragment contains $34 \mathrm{nt}$ which were similar to a holin sequence known from a Listeria phage (Loessner et al., 1995b).
After PCR-amplification from chromosomal DNA (for PCR primers see Methods), a major band with a size of about $300 \mathrm{bp}$ was found. Subcloning and sequencing revealed an ORF for a putative holin gene (bol2438, $291 \mathrm{nt}$, Fig. 5). The gene product HOL2438 consists of $95 \mathrm{aa}$ and has a calculated molecular mass of $10 \cdot 1 \mathrm{kDa}$ with a structure similar to other holin proteins (for details see discussion).

\section{Overexpression and lytic range of CPL2438}

E. coli JM109(DE3)(pCPL2438) cells were grown to $\mathrm{OD}_{600} 0.5$ before induction with $0.4 \mathrm{mM}$ IPTG, followed by further incubation and sampling at different times. Total protein content of the cells was determined with SDS-PAGE. Starting at $30 \mathrm{~min}$ after induction, we observed a $33 \mathrm{kDa}$ protein (Fig. $4 \mathrm{~b}$ ). The molecular mass is in agreement with that of the predicted phage endolysin. Production of CPL2438 increased steadily, reaching a maximum at $5 \mathrm{~h}$. Clones without addition of IPTG showed no expression. Lytic activity studies with more than 70 different Listeria strains (all species and serovars, detailed data not shown) revealed a rapid decrease in $\mathrm{OD}_{600}$ for all tested Listeria cells, indicating cell destruction. Apart from three Bacillus spp. (B. megaterium, $B$. polymyxa, $B$. subtilis), none of the other $38 \mathrm{Gram}$-positive strains tested (see Methods) showed sensitivity to CPL2438. 


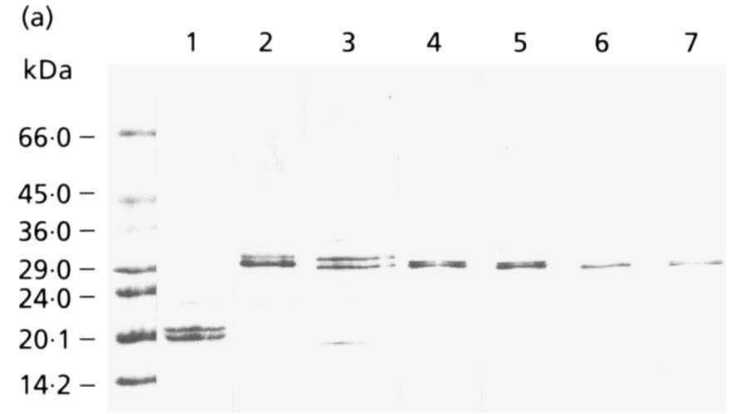

(b)

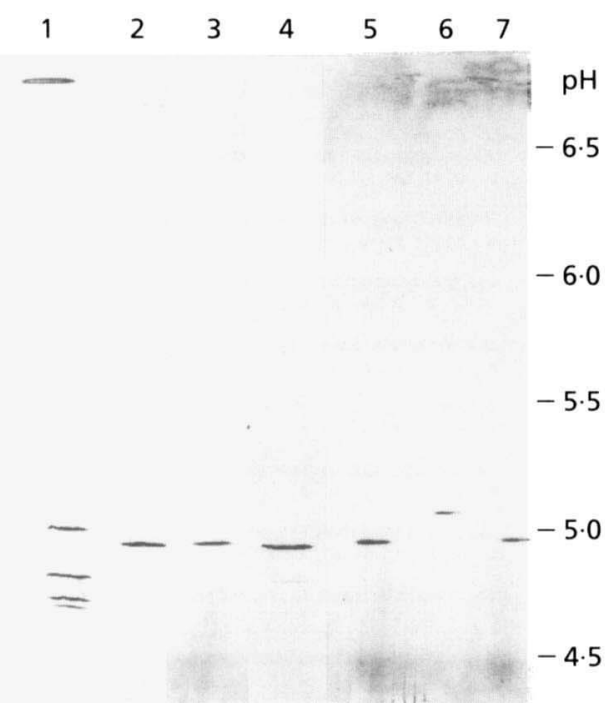

Fig. 2. Electrophoretic analyses of monocin proteins. Lanes: 1 , M1040; 2, M1034; 3, M1132; 4, M2011; 5, M2438; 6, M3010; 7, M5008. (a) SDS-PAGE protein profiles. Molecular masses of the marker proteins (SDS-7L, Sigma) are indicated on the left. (b) Isoelectric focusing in immobilized $\mathrm{pH}$ gradients. The linear $\mathrm{pH}$ gradient is indicated on the right.

\section{DISCUSSION}

Bactericidal substances are produced by L. monocytogenes (Curtis \& Mitchell, 1992; Hamon \& Péron, 1963; Mollerach et al., 1988; Ortel, 1978; Wilhelms \& Sandow, $1989)$, but were not studied in structural detail. Sword \& Pickett (1961) reported that their Listeria strains produced substances 'possibly analogous to colicins or colicin-like agents'. Using electron microscopy, we observed structures which are similar to non-contractile, flexible phage tails (Fig. 1). Bradley \& Dewar (1966) described longer particles (240 vs $120 \mathrm{~nm}$ ), which resemble contractile phage tails. In no case did we observe monocins resembling contractile phage tails. All monocins differ from structures described for E. coli (Medoff \& Swartz, 1969), Pseudomonas spp. (R-type 'Pyocins'; Ishii et al., 1965; Higerd et al., 1969; Shinomiya \& Shiga, 1979) or Bacillus (Steensma \& Robertson, 1978; Steensma et al., 1978; Wood et al., 1990). Protein profiles showed that six of the seven monocins investigated (except M1040) exhibited patterns relatively similar and therefore would (a)
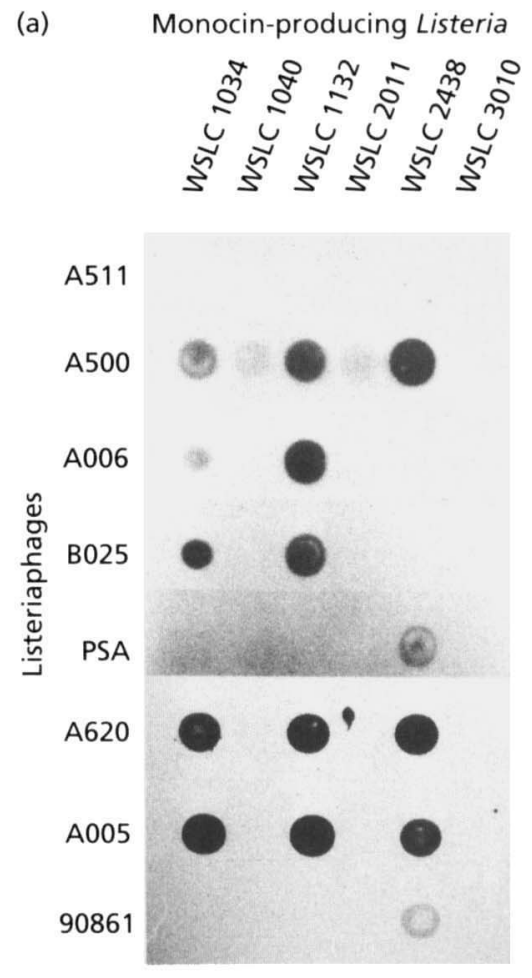

(b)

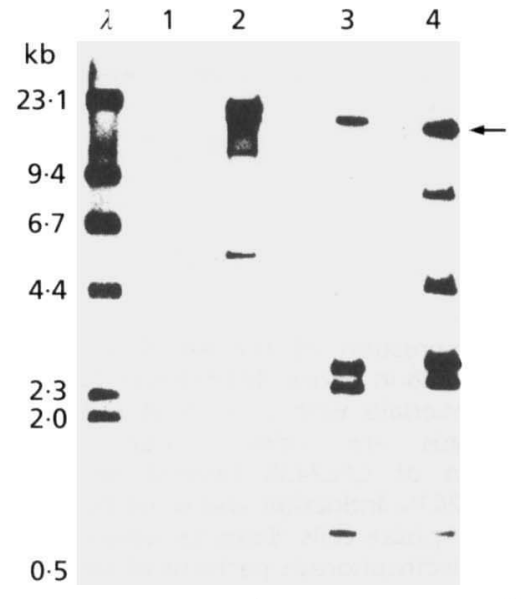

Fig. 3. (a) Dot-blot hybridization of membrane-bound DNA of six monocin-producing Listeria strains (WSLC 1034, 1040, 1132, 2011, 2438 and 3010) to digoxigenin-labelled listeriaphage DNA (A511, A500, A006, B025, PSA, A620, A005, 90861); (b) Southern-blot hybridization of Clal-digested chromosomal DNA fragments from monocin-carrying Listeria strains WSLC 1040, 1132 and 2438 . Fragments were separated by electrophoresis $(0.8 \%$ agarose gels) and hybridized to digoxigenin-labelled listeriaphage DNA. Lanes: $\lambda$, molecular mass markers; 1 , WSLC1040/phage A005; 2, WSLC 1132/phage A005; 3, WSLC 2438/phage A500; 4, WSLC 2438/phage A620. Arrow indicates endolysin-encoding fragment of WSLC 2438, identified with digoxigenin-labelled probe PCPL2438

seem to be related to each other (Fig. 2). When compared to Listeria phage-protein profiles (Loessner et al., 1994a, b; Zink \& Loessner, 1992), monocin proteins correspond in molecular mass and $\mathrm{pI}$ with major proteins of phage 
(a)

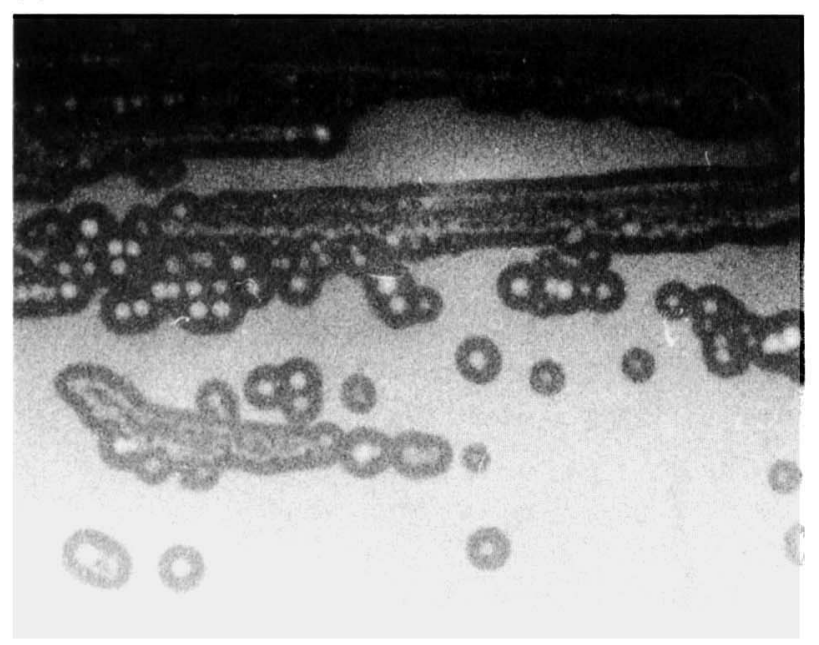

(b)

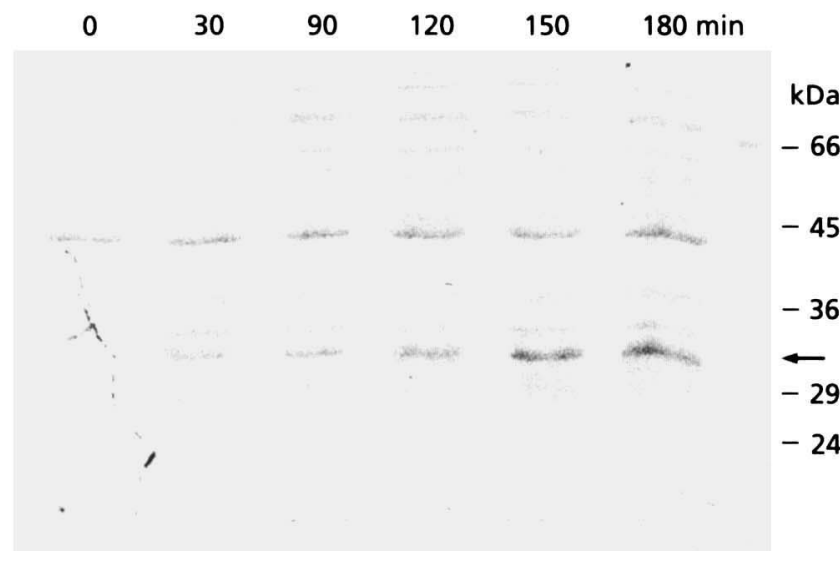

Fig. 4. (a) Expression of the endolysin gene cp/2438 from plasmid pCPL2438 in E. coli JM109(DE3). Cells were chloroformtreated and overlaid with a lawn of Listeria cells. Distinctive zones of lysis are visible around the colonies; (b) Overexpression of CPL2438 (arrow) in E. coli JM109(DE3) carrying PCPL2438. Induction was done by adding $0.4 \mathrm{mM}$ IPTG to exponential-phase cells. Samples were collected at indicated time-points. Electrophoresis patterns of total cell proteins were determined by SDS-PAGE.

tails. It was, therefore, not surprising that $75 \%$ of the Listeria phage DNAs hybridized to DNA of monocinproducing listeriae.

Based on these data, we conclude that monocins are inducible defective prophages, which are present, if at all, in very low numbers in non-induced bacterial cultures. Since most of the genetic information for a Siphovirus (35-40 kb) may still be present in monocin-carrying Listeria (Fig. 3b), we suggest that errors in phage morphogenesis rather than extensive deletions are leading to incompletely assembled phages.

Our observation that none of the monocins inhibited any other Gram-positive bacteria is in contrast to earlier reports stating that monocins display a much broader activity spectrum and are active against $30 \%$ of Stapby-
1

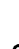

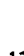

.

190

253

315

378

44

504

567

630

693

756

919

882

945

1008

1071

1134

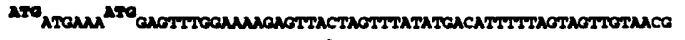

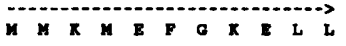

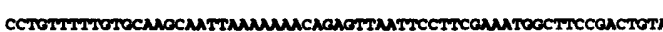

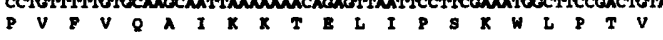

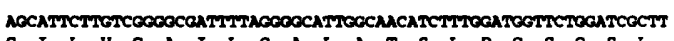
S I L V G A I L G A L A T S L D G S G S L

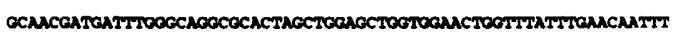
A T I I W A G A L A G A O G T G L F B $Q$ Tedi RBS

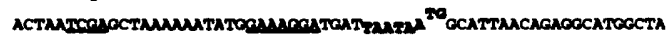
T N R A X K Y O K D D * M A L T E A WL L

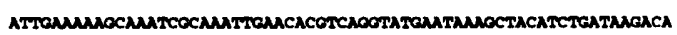

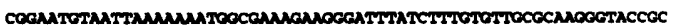

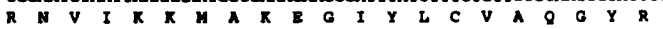

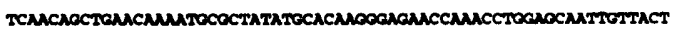
S TA E Q NA L Y A Q G R T X P G A I V T

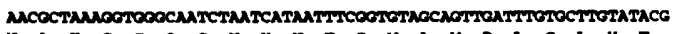
N A X G G

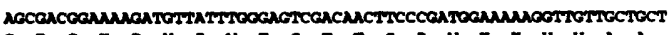

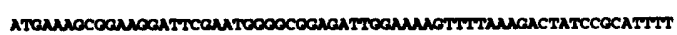
M X E G F E G O D W K S F X D Y P I P

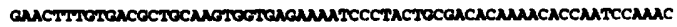
E L C D A A

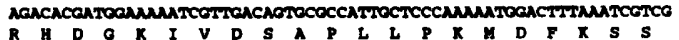

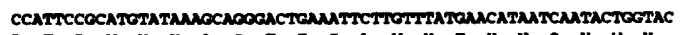

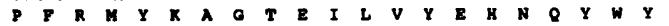

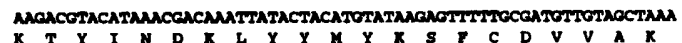

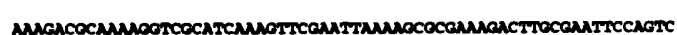
K D A K G R I K V R I K 8 A K D I R I P V

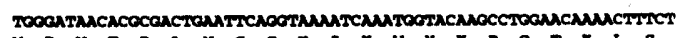
W D T R L S G K I K Y K P G T K L S

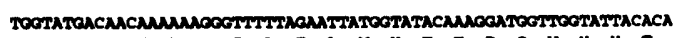
W Y D N R O T L E L W Y T K D C W Y Y T

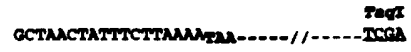

A $Y$ L $R$. I E K A N R K L N T S G M N K A T S D K T

Fig. 5. Nucleotide sequence and inferred amino acid sequence of the cp/2438 (nt 291-1154) and putative ho/2438 gene (1/10-291). The DNA sequence of $\mathrm{nt} 1-257$ was determined after PCR-amplification. PCR primers are indicated by dashed lines. A potential RBS (nt 275-281) for $c p /$ is underlined; start codons are in raised letters and stop codons are in lowered letters and are designated with asterisks.

lococcus spp. and Bacillus spp. tested (Hamon \& Péron, 1963; Ortel, 1978). Regarding the strictly genus-specific action of Listeria phages (Loessner \& Busse, 1990; Loessner, 1991), transgeneric inhibition is most probably not due to defective phages. This would also explain the contradiction between our finding that only a relatively small fraction of Listeria strains $(17 \%)$ produce true defective phages and reports of other groups, which stated that $58 \%$ (Wilhelms \& Sandow, 1989), 76\% (Ortel, 1978) or $98 \%$ (Curtis \& Mitchell, 1992) of Listeria strains produce bactericidal substances. Following Bradley \& Dewar (1966), and in order to clarify the nomenclature, we suggest that the term 'monocin' should be used only when the bactericidal principle is a defective phage particle, as confirmed by electron microscopy. In all other cases, the term 'bacteriocin' or ' listeriocin' seems to be more adequate (Curtis \& Mitchell, 1992; Mollerach $e t$ al., 1988). 
From previous studies with defective phages of $B$. subtilis (Steensma, 1981), it was concluded that the target of lytic activity could be either the cell wall or the cell membrane. Adsorption occurs at a cell-wall receptor and isolated defective phages were shown to kill without irreversible adsorption. In other defective prophages (Foster, 1993) and bacteriophages (Young, 1992), lytic enzymes have been identified as the killing principle. For the defective Bacillus phage PBSX, Longchamp et al. (1994) clearly identified host lysis genes inserted between structural and regulative genes.

Until now, no information about the molecular killing mechanism of monocins was available. We observed monocin-induced lysis of listerial cells (Fig. 1d), which indicates the presence of a lytic enzyme in monocins. A $2 \cdot 1 \mathrm{~kb}$ fragment isolated from an expression library clearly showed a lytic phenotype which is due to the synthesis of a $33 \mathrm{kDa}$ protein (Fig. 4), most probably an endolysin, corresponding to an 864 bp ORF, cpl2438 (Fig. 5). No homologous proteins were found in protein database searches. Labelled $c p l 2438$ did not hybridize to DNA from all monocin-producing strains, suggesting different lysin gene structures. No ORF could be identified downstream of $c$ p 2438 , although hybridization to Listeria phage-DNA was found. Our data, however, do not suggest regulative functions for these sequences.

The endolysin gene cpl2438 is preceded by a small ORF, designated bol2438, encoding a 95 aa hydrophobic protein. Although no similarity to other proteins was found in database searches, motifs such as transmembrane segments and spatial distribution of $\alpha$-helices and $\beta$-turns (data not shown) were clearly similar to holins described for other bacteriophages (for review see Young, 1992), especially for Listeria phages (Loessner et al., 1995b). This similarity includes a dual start motif, permitting synthesis of two different proteins enabling the regulation of the pore-forming process (for details see lambdoid $S$ gene in Young, 1992), and an overlap of the putative stop codon of bol2438 and the putative start codon of cpl2438 (Fig. 5). Holins were shown to form pores in the cytoplasmic membrane, providing access for the endolysin to the cell wall of the host cell (Young, 1992). Clearly, the expression of holins is expected to be lethal. From sequence analysis of nine clones of the PCR amplified putative holin gene we have found that subcloning of this gene was only possible when it was inserted in a $3^{\prime} \rightarrow 5^{\prime}$ direction distally from the T7 promoter of pSP72, leading only to transcription of the non-coding strand and, thus, effectively preventing expression (cf. Steiner et al., 1993; Young, 1992).

Other results of our laboratory clearly show a similar organization of the cloned lysis cassettes (holin and endolysin) of defective and intact phages of Listeria (Loessner et al., 1995b). The temperate siphoviral phage A500 harbours the lysis gene ply500 (867 nt) which encodes a phage lysin of 289 aa with $33.4 \mathrm{kDa}$. Overall DNA sequence identity between cpl2438 and ply500 is $86 \%$, and $95 \%$ between bol 2438 and the A500 holin gene. From our data we conclude that the monocin-producing
L. innocua WSLC2438, among other genes of a defective prophage, harbours a functional phage holin-endolysin system derived from a Listeria phage. Certainly, this system is used for cell lysis when monocins are produced (lysis from within). Monocin-induced lysis of sensitive listeriae (lysis from without) is coupled to an adsorption of monocins to the cell wall (Fig. 1d). However, whether the cloned lysin, perhaps as part of the baseplate or receptor structure of the defective phage, indeed contributes to the lytic mechanism of monocins, is not yet proven.

\section{ACKNOWLEDGEMENTS}

We wish to thank Dr H.-Ch. Bartscherer (Freising, Germany) for helpful discussions and for providing the electron microscopy facility. This work was supported by the Bayerisches Staatsministerium für Ernährung, Landwirtschaft und Forsten (Munich, Germany).

\section{REFERENCES}

Arendt, E. K., Daly, C., Fitzgerald, G. F. \& van de Guchte, M. (1994). Molecular characterization of lactococcal bacteriophage Tuc2009 and identification and analysis of genes encoding lysin, a putative holin, and two structural proteins. Appl Environ Microbiol 60, 1875-1883.

Bradley, D. E. (1967). Ultrastructure of bacteriophages and bacteriocins. Bacteriol Rev 31, 230-314.

Bradley, D. E. \& Dewar, C. A. (1966). The structure of phage-like objects associated with non-induced bacteriocinogenic bacteria. $J$ Gen Microbiol 45, 399-408.

Curtis, G. D. W. \& Mitchell, R. G. (1992). Bacteriocin (monocin) interactions among Listeria monocytogenes strains. Int J Food Microbiol 16, 283-292.

Dower, W. J., Miller, J. F. \& Ragsdale, C. W. (1988). High efficiency transformation of $E$. coli by high voltage electroporation. Nucleic Acids Res 16, 6127-6145.

Foster, S. J. (1993). Analysis of Bacillus subtilis 168 prophageassociated lytic enzymes; identification and characterization of CWLA-related prophage proteins. J Gen Microbiol 139, 3177-3184.

Garro, A. J. \& Marmur, J. (1970). Defective bacteriophages. J Cell Pbysiol 76, 253-264.

Hamon, Y. \& Péron, Y. (1963). Étude du pouvoir bactériocinogène dans le genre Listeria. Ann Inst Pasteur 104, 55-65.

Henrich, B., Binishofer, B. \& Bläsi, U. (1995). Primary structure and functional analysis of the lysis genes of Lactobacillus gasseri bacteriophage adh. J Bacteriol 177, 723-732.

Higerd, T. B., Baechler, C. A. \& Berk, R. S. (1969). Morphological studies on relaxed and contracted forms of purified pyocin particles. J Bacteriol 98, 1378-1389.

Hoover, D. G. (1992). Bacteriocins: activities and applications. In Encyclopedia of Microbiology, vol. 1, pp 181-190. Edited by J. Lederberg. New York: Academic Press.

Ishii, S. I., Nishi, Y. \& Egami, F. (1965). The fine structure of a pyocin. J Mol Biol 3, 428-431.

Ito, S. I., Nishimune, T., Abe, M., Kimoto, M. \& Hayashi, R. (1986). Bacteriocin-like killing action of a temperate bacteriophage phiBA1 of Bacillus aneurinolyticus. J Virol 59, 103-111.

Loessner, M. J. (1991). Improved procedure for bacteriophage typing of Listeria strains and evaluation of new phages. Appl Environ Microbiol 57, 882-884. 
Loessner, M. J. \& Busse, M. (1990). Bacteriophage typing of Listeria species. Appl Environ Microbiol 56, 1912-1918.

Loessner, M. J., Estela, L. A., Zink, R. \& Scherer, S. (1994a). Taxonomical classification of 20 newly isolated Listeria bacteriophages by electron microscopy and protein analysis. Intervirology 37, 31-35.

Loessner, M. J., Krause, I. B., Henle, T. \& Scherer, S. (1994b). Structural proteins and DNA characteristics of 14 Listeria typing bacteriophages. J Gen Virol 75, 701-710.

Loessner, M. J., Schneider, A. \& Scherer, S. (1995a). A new procedure for efficient recovery of DNA, RNA, and proteins from Listeria cells by rapid lysis with a recombinant bacteriophage endolysin. Appl Environ Microbiol 61, 1150-1152.

Loessner, M. J., Wendlinger, G. \& Scherer, S. (1995b). Heterogenous endolysins in Listeria monocytogenes bacteriophages: a new class of enzymes and evidence for conserved holin genes within the Siphoviral lysis cassettes. Mol Microbiol 16, 1231-1241.

Longchamp, P. F., Mauël, C. \& Karamata, D. (1994). Lytic enzymes with defective prophages of Bacillus subtilis: sequencing and characterization of the region comprising the $N$-acetylmuramoyl-Lalanine amidase gene of prophage PBSX. Microbiology 140, 18551867.

Medoff, G. \& Swartz, M. N. (1969). Induction of a defective phage

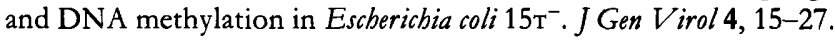

Mollerach, M. E., Ogueta, S. B. \& De Torres, R. A. (1988). Production of Linnocuicina 819 , a bacteriocin produced by Listeria innocua. Microbiologica 11, 219-224.

Moody, M. F. (1967). Structure of the sheath of bacteriophage T4. J Mol Biol 25, 167-200.

Ortel, S. (1978). Untersuchungen über Monocine. Zentralbl Bakteriol Hyg 1 Abt Orig A 242, 72-78.

Reeves, P. (1972). The bacteriocins. Mol Biol Biochem Biophys 11.

Reichle, R. E. \& Lewin, R. A. (1967). Purification and structure of rhapidosomes. Can J Microbiol 14, 211-213.

Sambrook, J., Fritsch, E. F. \& Maniatis, T. (1989). In Molecular Cloning: a Laboratory Manual, 2nd edn. Cold Spring Harbor, NY: Cold Spring Harbor Laboratory.

Shearman, C., Jury, K. \& Gasson, M. (1994). Controlled expression and structural organization of a Lactococcus lactis bacteriophage lysin encoded by two overlapping genes. Appl Environ Microbiol 60, 3063-3073.

Shinomiya, T. \& Shiga, S. (1979). Bacteriocidal activity of the tail of Pseudomonas aeruginosa bacteriophage PS 17. J Virol 32, 958-967.

Steensma, H. Y. (1981). Adsorption of the defective phage PBSZ 1 to Bacillus subtilis 168WT. J Gen Virol 52, 93-101.

Steensma, H. Y. \& Robertson, L. A. (1978). Lysogeny in Bacillus. FEMS Microbiol Lett 3, 313-317.

Steensma, H. Y., Robertson, L. A. \& Van Elsas, J. D. (1978). The occurrence and taxonomic values of PBSX-like defective phages in the genus Bacillus. Antonie Leeuwenboek 44, 353-366.

Steiner, M., Lubitz, W. \& Bläsi, U. (1993). The missing link in phage lysis of gram-positive bacteria: gene 14 of Bacillus subtilis phage phi 29 encodes the functional homolog of lambda $S$ protein. $J$ Bacteriol 175, 1038-1042.

Sword, C. P. \& Pickett, M. J. (1961). The isolation and characterization of bacteriophages from Listeria monocytogenes. $J$ Gen Microbiol 25, 241-248.

Tagg, J. R., Dajani, A. S. \& Wannamaker, L. W. (1976). Bacteriocins of gram-positive bacteria. Bacteriol Rev 40, 722-756.

Wilhelms, D. \& Sandow, D. (1989). Preliminary studies on monocine typing of Listeria monocytogenes strains. Acta Microbiol Hung 36, 235-238.

Wood, H. E., Dawson, M. T., Devine, K. M. \& McConnell, D. J. (1990). Characterization of PBSX, a defective prophage of Bacillus subtilis. J Bacteriol 172, 2667-2674.

Yamamoto, K. R., Alberts, B. M., Benzinger, R., Lawhorne, L. \& Treiber, G. (1970). Rapid bacteriophage sedimentation in the presence of polyethylene glycol and its application to large-scale virus purification. Virology 40, 734-744.

Young, R. (1992). Bacteriophage lysis : mechanism and regulation. Microbiol Rev 56, 430-481.

Zink, R. \& Loessner, M. J. (1992). Classification of virulent and temperate bacteriophages of Listeria spp. on the basis of morphology and protein analysis. Appl Environ Microbiol 58, 296-302.

Zink, R., Loessner, M. J., Glas, I. \& Scherer, S. (1994). Supplementary Listeria-typing with defective Listeria-phage particles (monocins). Lett Appl Microbiol 19, 99-101.

Received 10 March 1995; revised 28 June 1995; accepted 5 July 1995. 